\title{
Anti-inflammatory effect potentials of ethanol extracts from fermentated Caryopteris incana by Lactobacillus plantarum on induced to LPS with Raw 264.7 cell
}

\author{
Mi-Jeong Park ${ }^{1} \cdot$ Hye-Jin Park ${ }^{1}$ (D) Eun-Ho Lee ${ }^{1} \cdot$ Hee-Young Jung ${ }^{2}$. \\ Young-Je Cho' ${ }^{1}$ (D)
}

\section{LPS로 유도된 Raw 264.7 cell에서 Lactobacillus plantarum 발효가 충꽃나무(Caryopteris incana) 에탄올 추출물의 염증반웅에 미치는 영향}

\author{
박미정 ${ }^{1} \cdot$ 박혜진 $^{1} \cdot$ 이은호 ${ }^{1} \cdot$ 정희영 ${ }^{2} \cdot$ 조영제 ${ }^{1}$
}

Received: 7 February 2018 / Accepted: 16 April 2018 / Published Online: 30 June 2018

(C) The Korean Society for Applied Biological Chemistry 2018

\begin{abstract}
In this study, the inflammation of ethanol extracts from Caryopteris incana (CI) and fermented C. incana (FCI) on induced to lipopolysaccharide with Raw 264.7 cell was tested. The composition profile of $L$. plantarum was changed by fermentation, and confirmed by HPLC analysis. We performed the 3-[4,5-dimethylthiazol]-2-yl]-2,5-diphenyltetrazolium bromide assay to evaluate the toxicity of CI and FCI extracts. In cell viability, cell toxicity was not shown at 5,10 and $15 \mu \mathrm{g} / \mathrm{mL}$ of CI extracts and 10,20, 30 and $40 \mu \mathrm{g} / \mathrm{mL}$ of FCI extracts. The results of inducible nitric oxide synthase and cyclooxygenase-2 protein production were confirmed to be inhibitory in a concentrationdependent manner, respectively. Additionally, protein expression of nitric oxide and prostaglandin $\mathrm{E}_{2}$ by $\mathrm{CI}$ and $\mathrm{FCI}$ extracts were also inhibited in a concentration-dependent manner. In the result
\end{abstract}

Young-Je Cho $(\bowtie)$

E-mail: yjcho@knu.ac.kr

${ }^{1}$ School of Food science \& Biotechnology/Food \& Bio-Industry Research Institute, Kyungpook National University, 80 University Street, Bukgu, Daegu 41566, Republic of Korea

${ }^{2}$ School of Applied Biosciences, Kyungpook National University, Daegu 41566, Republic of Korea

This is an Open Access article distributed under the terms of the Creative Commons Attribution Non-Commercial License (http://creativecommons. org/licenses/by-nc/3.0/) which permits unrestricted non-commercial use, distribution, and reproduction in any medium, provided the original work is properly cited. of pro-inflammatory cytokine, $15 \mu \mathrm{g} / \mathrm{mL}$ concentration of CI extracts was showed tumar necrosis factor (TNF)- $\alpha$ (57.3\%), interleukin (IL)-6 (35.2\%), and IL-1 $\beta$ (48.0\%), respectively. And $40 \mu \mathrm{g} / \mathrm{mL}$ of FCI extracts was showed TNF- $\alpha$ (34.6\%), IL-6 (32.1\%), and IL-1 $\beta$ (30.0\%), respectively. These results suggest that FCI extracts showed better effect of anti-inflammatory than CI extracts. Therefore, it was found that both CI and FCI can be used as an excellent material for the development of new antiinflammatory resource.

Keywords Anti-inflammation · Caryopteris incana $\cdot$ Fermentation - Lactobacillus plantarum · Raw 264.7 cell

\section{서 론}

염증반응은 외부 자극에 대한 생체조직의 방어 반응으로써 정 상적인 상태에서는 항원항체 반응을 통해 질병을 일으키는 항 원을 제거 하지만, 비정상적인 상태의 만성염증반응의 경우, 특 정한 조직을 손상시키고 아토피, 관절염, 건선 등과 같은 각종 질환을 유발한다[1]. 면역체계에서 대식세포(macrophage)는 활 성산소, stress 등과 같은 여러 가지 자극에 의해 발현되는 염 증반응을 억제하여 면역기능을 조절하고 체내 항상성 유지에 매 우 중요한 역할을 한다[2]. 그람음성균(gram-negative bacteria)의 외막 성분에 존재하는 lipopolysaccharide (LPS)는 대식세포 막 수용체인 TLR-4를 통해 세포 내부로 신호를 전달한다[3]. 중요 
한 염증 매개 물질인 transforming growth factor $\beta$-activated kinase 1 (TAK1)은 효소 복합체인 inhibitory kappa B kinase $\beta$ 를 인산화 시키는데, 이를 통해 활성화 된 IKK $\beta$ 가 nuclear factor-kappa B (NF-kB)의 억제 인자인 inhibitory kappa B $\mathrm{alpha}$ 를 분해하게 되고 활성화된 NF- $\mathrm{KB}$ 는 핵 내로 이동한다[4, 5]. 결과적으로 핵 내로 이동된 NF- $\mathrm{NB}$ 는 inducible nitric oxide synthase (iNOS)와 cyclooxygenase (COX)-2와 같은 염증성 효 소와 interleukin (IL)-6, IL-1 $\beta$, Tumor necrosis factor (TNF)$\alpha$ 같은 pro-inflammatory cytokine 발현을 일으킨다[6]. iNOS는 L-arginine이 L-citrulline으로 변환되는 과정에 관여하여 많은 양 의 $\mathrm{NO}$ 를 생성하고 염증과 관련된 질병을 유발하며[7], $\mathrm{COX}-2$ 는 arachidonic acid가 발열과 통증에 작용하는 염증 유발 물질 인 prostaglandin $\mathrm{E}_{2}\left(\mathrm{PGE}_{2}\right)$ 로 바뀌는 과정에 관여한다[8].

층꽃나무(Caryopteris incana)는 다년초로 한국, 중국, 타이완, 일본에 걸쳐 널리 분포하고 있으며 한국에서는 주로 산과 들에 서식한다. 30-60 cm 높이의 줄기는 곧추서고 기부가 목질이며, 화서는 층층으로 배열되고, 검은색을 띠는 열매는 9-10월에 열 린다[9]. 전초 또는 뿌리를 약용하며, 생약명은 난향초(蘭香草) 라 한다. 층꽃나무의 전초에는 flavonoid 배당체와 phenol류, alkaloid, steroid, amino acid, 유기산, tannin을 함유하고 있으며 $[10,11,12]$, 수렴작용, 기침, 가래, 기관지염, 신경통, 종기, 월경 불순, 어혈, 타박상, 습진, 피부, 가려움증 치료에 쓰이고 Staphylococcus aureus, Corynebacterium diphtheriae에 대한 항 균작용이 있는 것으로 알려져 있다[13].

한편, 유산균, 효모 등의 미생물은 외부로부터 영양성분을 세 포 내로 섭취하면, 영양성분들은 미생물 내의 효소에 의해 분 해되는 대사(metabolism)과정을 거치면서 발효대사산물로 전환 된다[14]. 이러한 미생물을 이용하여 천연물을 발효할 경우 total polyphenol 및 flavonoid 함량 증가, 항산화 효과 증가, 세포 독 성 감소 등의 다양한 이점이 나타나며, 특히 천연물 중 하나인 한약재를 발효할 경우 약효 성분의 체내 흡수율이 증가되는 것 으로 보고되고 있다 $[15,16]$. 최근 미생물을 이용한 발효 기술이 진보하면서 천연물에 이를 적용하여 생리활성 효능을 증가시키 거나 변환시키는 발효산물에 대한 연구가 증대되고 있는데, 그 예로 Sacharomyces cerevisise을 이용하여 발효한 홍삼에서 면 역 증강 및 항염증 효과가 상승되는 결과가 보고된 바 있으며 [17], Lactobacillus rhamnosus HK-9 발효에 의한 배초향 잎 추출물은 피부의 항산화 및 항염증 활성이 증대되는 것으로 나 타나[18] 천연물을 이용하여 미생물 발효 기술을 적용한 연구 와 제품 개발에 대한 기대가 높아지고 있다.

본 연구에서는 자연계에서 가장 넓게 분포하는 것으로 알려 진 젖산균의 일종인 Lactobacillus plantarum을 이용하여 발효 한 층꽃나무의 추출물을 이용하여 $\mathrm{LPS}$ 를 처리해 염증반응을 유 도한 Raw 264.7 cell에서의 항염증 효능의 변화를 확인하고자 하였다. 이를 위해 추출물이 염증반응에 관여하는 $\mathrm{NO}$ 및 $\mathrm{PGE}_{2}$ 생성량과 $\mathrm{iNOS}$ 및 $\mathrm{COX}-2$ 단백질 발현 억제 정도를 확인하고, 더 나아가 pro-inflammatory cytokine 발현 정도에 미치는 영향 을 비교 조사하여 층꽃나무가 생산하는 천연물에 의한 항염증 소재 개발의 가능성을 확인하여 산업화 이용을 위한 기초 자료 로 활용하고자 하였다.

\section{재료 및 방법}

\section{실험재료}

본 실험에서 사용된 층꽃나무(C. incana)는 경기도 파주 소재의 농장에서 판매되는 원물을 구입하여 사용하였고, 전초를 $50{ }^{\circ} \mathrm{C}$ dry oven (Jeiotech, Daejeon, Korea)에서 건조시킨 후, 40 mesh로 분쇄하여 일정한 입자로 분리한 다음 진공 포장하여 $4{ }^{\circ} \mathrm{C}$ 에서 저온 저장하며 시료로 사용하였다.

\section{시약 및 기기}

페놀 함량 측정에 사용된 Folin-Ciocalteu reagent는 Junsei (Tokyo, Japan)사에서, HPLC용 methanol은 Duksan Pure Chemical Co., Ltd. (Gyeonggi, Korea)에서 구입하였다. 세포 배양 시 사용한 dulbecco's modified eagles medium (DMEM), fetal bovine serum (FBS), penicillin/streptomycine 등은 Hyclone (Logan, UT, USA)사에서 구입하였으며, 3-(4,5-dimethylthiazol2-yl)-2,5-diphenyltetrazolium bromide (MTT), methyl ulfoxide (DMSO), LPS 는 Sigma (St. Louis, MO, USA)사, phosphate buffered saline (PBS)는 Gibco (Gibco, Grand Island, NY, USA)사에서 구입하여 사용하였다. Mammalian protein extraction reagent (M-PER)와 protease inhibitor cocktail은 Thermo-Fisher Scientific (San Joes, CA, USA)사, 1차 antibody는 COX-2는 Cayman (Ann Arbor, MI, USA), iNOS는 Santa Cruz Biotechnology Inc. (Santa Cruz, CA, USA), GAPDH는 Thermo (Wilmington, $\mathrm{DE}, \mathrm{USA}$ )에서 각각 구입하였으며, 2차 antibody는 Santa cruze biotechnology Inc.에서 구입하여 사용하였다. Griess reagent system은 Promega (Madison, WI, USA), TNF- $\alpha$, IL-1 $\beta$ 와 IL-6, $\mathrm{PGE}_{2}$ 의 ELISA kit는 R\&D systems (Minneapolis, MN, USA)사에서 구입하였으며, 그 외의 시약들은 특급 시약을 사용 하였다. 측정 기기는 UV-Vis spectrophotometer (Optizen 3220UV, Mecasys, Daejeon, Korea), HPLC (HP series 1100, Hewlett Packard, Walbronn, Germany), SPECTRO star Nano ELISA reader (BMG LabTech, Ortenberg, Germany), C 300 image analyzer (Azure biosystems, Dublin, CA, USA) 등을 사용하여 측정하였다.

\section{젓산균 L. plantarum 배양}

본 실험에서 사용한 L. plantarum은 가자미식해에서 분리한 균 으로 경북대학교 식품공학부에서 보관중인 균주를 사용하였다. 균주의 보존은 균 배양액으로 $12 \%$ glycerol (Junsei Chemical) 이 되도록 조성하여 $-70{ }^{\circ} \mathrm{C}$ deep freezer에서 보관하며 사용하 였다. Conical tube에서 MRS broth $\left(\mathrm{Difco}^{\mathrm{TM}}\right.$ Lactobacilli MRS, Becton Dickinson, Sparks, MD, USA) 배지 $5 \mathrm{~mL}$ 에 1 회 계대 배양한 후, 삼각 플라스크에 MRS broth 배지 300 $\mathrm{mL}$ 에 젖산균 배양액을 접종하여 $37^{\circ} \mathrm{C}$ incubator에서 24 시간 정 치배양으로 증균하였다. 증균 배양한 젖산균 배양액 $1 \mathrm{~mL}$ 를 십 진 희석법을 사용하여 $10^{-10}$ 으로 희석하고, $0.1 \mathrm{~mL}$ 를 $\mathrm{MRS}$ agar 평판 배지에 도말하여 $37^{\circ} \mathrm{C}$ incubator에서 24시간 증균 배양하였으며, 이를 동결건조하여 $-70{ }^{\circ} \mathrm{C}$ deep freezer에서 보 관하며 사용하였다. 


\section{충꽃나무 발효 및 추출물 제조}

층꽃나무 발효는 멸균한 건조 층꽃나무 전초 시료 $10 \mathrm{~g}$ 에 2회 차 계대한 L. plantarum 배양액을 $5 \mathrm{~mL}$ 접종하여 $37^{\circ} \mathrm{C}$ incubator에서 24시간 동안 정치배양 하였다. 추출물 제조는 [19] 이 보고한 층꽃나무 전초를 이용한 추출 최적 조건인 $80 \%$ ethanol을 추출 용매로 선정하여 층꽃나무 추출물과 발효된 층 꽃나무 추출물을 각각 제조하였다. 층꽃나무 및 발효된 층꽃나 무 전초 분말 각각 $10 \mathrm{~g}$ 을 준비하고 $80 \%$ ethanol $100 \mathrm{~mL}$ 에 침지하여 24시간 동안 상온에서 교반 추출하였으며, 추출액은 Whatman No.1 filter paper (Whatman, Maidstone, UK)로 여 과한 후 rotary vacuum evaporator (Eyela NE, Tokyo, Japan) 를 이용하여 추출용매인 $80 \%$ ethanol을 모두 제거하고 사용하 였다. Raw 264.7 cell에서 염증 억제 효과 측정을 위해 여과한 추출물을 동결건조하고 $-20{ }^{\circ} \mathrm{C}$ 에서 보관하여 필요한 함량을 맞 추어 사용하였다.

\section{총 페놀 함량 측정}

층꽃나무와 발효층꽃나무의 총 페놀 함량 측정은 Folin과 Denis 의 방법[20]에 준하여 측정하였으며, 시료 추출물 $1 \mathrm{~mL}$ 에 $95 \%$ ethanol $1 \mathrm{~mL}$ 와 증류수 $5 \mathrm{~mL}$ 를 첨가하고 $1 \mathrm{~N}$ Folin-Ciocalteu reagent $0.5 \mathrm{~mL}$ 를 넣어 잘 섞어주고 5 분간 방치한 후 반응 종 료시약으로 $5 \% \mathrm{Na}_{2} \mathrm{CO}_{3} 1 \mathrm{~mL}$ 를 첨가하고 잘 혼합하여 1시간 동안 암실에서 방치한 후 UV-Vis spectrophotometer를 사용하 여 $725 \mathrm{~nm}$ 에서 흡광도를 측정하였다. 총 페놀 함량은 표준물질 로 gallic acid (Sigma)를 이용한 표준곡선을 통해 함량을 환산 하였다.

\section{HPLC를 이용한 phenolic profile 분석}

층꽃나무와 발효층꽃나무의 phenolic profile 변화를 확인하기 위 해 층꽃나무 $80 \%$ ethanol 추출물 동결건조물과 발효 층꽃나무 $80 \%$ ethanol 추출물 동결건조물 HPLC용 methanol을 이용하여 $2 \mathrm{mg} / \mathrm{mL}$ 의 농도로 제조하였다. 이후 시료액을 $0.2 \mu \mathrm{m}$ syringe filter (13 mm GD/X disposable filter device, Whatman)로 여 과한 후, Table 1의 분석조건에 따라 HPLC로 분석하였다.

\section{세포 배양}

Murine 유래의 macrophage cell line인 Raw 264.7 cells은 한 국세포주은행(Korean Cell Line Research Foundation, Seoul, Korea)에서 구입하였으며, DMEM에 $10 \%$ FBS와 $1 \%$ penicillin

Table 1 Condition for operating HPLC in the analysis of $80 \%$ ethanol extracts from $C$. incana and fermented $C$. incana

\begin{tabular}{ll}
\hline \multicolumn{1}{c}{ Instrument } & \multicolumn{1}{c}{ HP HPLC series 1100 } \\
\hline Column & Nova-Pak C18 $(3.9 \mathrm{~mm} \times 150 \mathrm{~mm})$ Column \\
Column temp & 30 \\
Injection volume & $10 \mu \mathrm{L}$ \\
Mobile phase & Phase A: distilled water, \\
Phase B: $100 \%$ methanol $(\mathrm{A}: \mathrm{B}=30: 70)$ \\
Flow rate & $0.2 \mathrm{~mL} / \mathrm{min}$ \\
Retention time & $35 \mathrm{~min}$ \\
Detection & $230 \mathrm{~nm}$ \\
\hline
\end{tabular}

streptomycine을 혼합한 배지를 사용하여 $5 \% \mathrm{CO}_{2}$ incubator에 서 $37^{\circ} \mathrm{C}$ 의 조건으로 배양하였다.

\section{MTT assay에 의한 세포 독성 측정}

세포 독성 측정은 Carmichael 등[21]의 방법에 준하여 측정하 였다. Raw 264.7 cell을 48 well plate에 well 당 $1 \times 10^{4}$ 개의 cell을 분주하고 $5 \% \mathrm{CO}_{2}$ incubator에서 $37^{\circ} \mathrm{C}$ 로 24 시간 동안 배양시킨 후, 농도별로 조제한 시료를 $0.5 \mathrm{~mL}$ 첨가하여 $37^{\circ} \mathrm{C}$ 로 $5 \% \mathrm{CO}_{2}$ incubator에서 18시간 배양하였다. 여기에 $5 \mathrm{mg} /$ $\mathrm{mL} \mathrm{MTT} \mathrm{용액} 0.05 \mathrm{~mL}$ 를 첨가하고 4시간 동안 $5 \% \quad \mathrm{CO}_{2}$ incubator에서 반응시킨 후 배양액을 제거하고 $\mathrm{DMSO} 0.5 \mathrm{~mL}$ 를 이용하여 녹여주었다. 이를 SPECTRO star Nano ELISA reader $540 \mathrm{~nm}$ 에서 흡광도를 측정하여, 시료군의 흡광도 감소율 을 대조군과 비교하여 세포독성을 평가하였다.

\section{Western blot에 의한 iNOS 및 COX-2 단백질 분석}

6 well plate에 $5 \times 10^{5}$ 개의 cell을 분주하고 $5 \% \mathrm{CO}_{2}$ incubator 에서 $37^{\circ} \mathrm{C}$ 로 24 시간 배양한 후, 자극제로 LPS $10 \mu \mathrm{g} / \mathrm{mL}$ 를 처 리한 다음, 1 시간 후 농도별로 조제한 시료를 처리하여 18시간 동안 배양하고 PBS로 세척하였다. M-PER와 protease inhibitor cocktail을 혼합한 lysis buffer로 세포막을 파괴한 후 bovine serum albumin standard curve을 이용하여 protein을 정량하였다. $20 \mu \mathrm{L}$ 의 단백질을 $10 \%$ 의 SDS-PAGE에서 전기 영동하여 분리 한 다음 PVDF membrane으로 옮긴 후, 실온에서 1시간 동안 $5 \%$ skim milk 용액으로 blocking하여 background를 제거시켰 다. 1차 antibody는 COX-2, iNOS, GAPDH를 각각 1:200 비 율로 희석하여 $4{ }^{\circ} \mathrm{C}$ 에서 overnight한 다음 10 분 간격으로 TBST 로 3회 세척하였다. 2차 antibody는 Ig-G horseradish peroxidaseconjugated antibody를 사용하였으며, iNOS의 경우 1:200으로, $\mathrm{COX}-2$ 의 경우 $1: 1,000$ 으로 희석하여 상온에서 1 시간 30 분 동 안 반응시킨 후, 다시 10 분 간격으로 TBST로 3 회 세척하였다. 이후 ECL kit (EZ west Lumi plus, ATTO, Tokyo, Japan)와 반응시켜 C 300 image analyzer를 이용하여 밴드를 현상하고 정량하였다.

\section{NO 측정}

$\mathrm{NO}$ 생성량을 측정하기 위해 supernatant에 안정한 형태로 존재 하는 nitrite $\left(\mathrm{NO}_{2}^{-}\right)$로서 환원시켜 griess reagent system을 이용 하였다[22]. 96 well plate에 well 당 $5 \times 10^{4}$ 개의 cell을 $5 \%$ $\mathrm{CO}_{2}$ incubator에서 $37^{\circ} \mathrm{C}$ 로 24 시간 배양한 다음, 자극제로 LPS $10 \mu \mathrm{g} / \mathrm{mL}$ 를 처리하였다. 1시간 뒤 농도별로 조제한 시료를 처 리한 다음 24시간 동안 배양하고 supernatant를 모아 차광시키 며, griess reagent로 반응시켜 ELISA reader $540 \mathrm{~nm}$ 에서 흡광 도를 측정하였다. NO 생성량(\%)은 1-(absorbance of control/ absorbance of sample) $\times 100$ 으로 계산하였다.

\section{Pro-inflammatory cytokine 분비량 측정}

$\mathrm{PGE}_{2}, \mathrm{IL}-6, \mathrm{IL}-1 \beta$ 경우 96 well plate에 well 당 $1 \times 10^{5}$ 개 분 주하고, $\mathrm{TNF}-\alpha$ 의 경우 $3 \times 10^{5}$ 개를 분주한 다음 $5 \% \quad \mathrm{CO}_{2}$ incubator에서 $37^{\circ} \mathrm{C}$ 로 24시간 배양하였다. 이후 자극제로 LPS $2.5 \mu \mathrm{g} / \mathrm{mL}$ 을 처리하고 1시간 뒤, 농도별로 조제한 시료를 처리 하고 24시간 동안 $5 \% \mathrm{CO}_{2}$ incubator에서 배양하였다. 이후 세 
포 배양액을 이용하여 $\mathrm{PGE}_{2}$ 와 IL-6, IL- $1 \beta, \mathrm{TNF}-\alpha$ 의 분비량을 ELISA kit를 이용하여 측정하였다.

\section{통계처리}

모든 실험은 3회 반복 측정하였고 자료의 통계처리는 SPSS 23 for windows (Statistical Package for Social Science, Chicago, $\mathrm{IL}, \mathrm{USA})$ 를 이용하여 평균 \pm 표준편차(mean \pm standard deviation) 로 표시하였으며, 분산분석(ANOVA)과 Duncan의 다중범위검정 (Duncan's multiple range test)을 실시하여 시료간의 유의차를 $p<0.05$ 수준으로 비교 분석하였다.

\section{결과 및 고찰}

\section{젓산균을 이용한 충꽃나무 발효 추출물의 유용성분 변화}

L. plantarum 발효에 따른 층꽃나무 추출물의 유용성분을 추출 하기 위해 총 페놀 함량을 측정한 결과는 Table 2 와 같이 층꽃 나무 $80 \%$ ethanol 추출물의 경우 $108.55 \pm 2.84 \mathrm{mg} / \mathrm{g}$ 으로 나타 났으며, 발효한 층꽃나무 $80 \%$ ethanol 추출물의 경우 110.00

Table 2 Total phenolics contents of $80 \%$ ethanol extracts from C. incana and fermented C. incana

\begin{tabular}{cc}
\hline \hline Sample & Total phenolics contents $(\mathrm{mg} / \mathrm{g})$ \\
\hline C. incana & $108.55 \pm 2.84^{1)}$ \\
fermented C. incana & $110.00 \pm 5.65$ \\
\hline
\end{tabular}

${ }^{1)}$ Mean \pm standard deviation $(\mathrm{n}=3)$ $\pm 5.65 \mathrm{mg} / \mathrm{g}$ 으로 나타났다. 따라서 L. plantarum 발효에 따른 층 꽃나무 추출물의 총 페놀성분 함량의 용출량의 변화는 나타나 지 않는 것으로 확인되었다.

발효에 의한 층꽃나무와 발효층꽃나무 추출물의 유용성분의 profile 변화를 확인하기 위해 층꽃나무 $80 \%$ ethanol 추출물 동 결건조물과 발효 층꽃나무 $80 \%$ ethanol 추출물 동결건조물을 이용하여 HPLC 분석을 실시하였다. 그 결과, Fig. $1 \mathrm{~A}$ 와 같이 $2 \mathrm{mg} / \mathrm{mL}$ 층꽃나무 $80 \%$ ethanol 추출물 chromatogram에서는 총 10 종의 peak가 분리되었는데, retention time 4.3 분에서 $227.7 \mathrm{mAU}$, 5.2분에서 $723.5 \mathrm{mAU}$ 의 매우 높은 peak를 나타내 었으며, 이후 retention time 8.6, 10.6, 11.8, 12.9, 13.6, 21.0, $22.6,29.4$ 분에서 $10 \mathrm{mAU}$ 이하의 낮은 peak가 다수 나타났다. 반면, 발효 $2 \mathrm{mg} / \mathrm{mL}$ 층꽃나무 $80 \%$ ethanol 추출물의 chromatogram에서는 총 4종의 peak가 분리되었으며, retention time 4.3분에서 $154.2 \mathrm{mAU}, 5.2$ 분에서 $588.9 \mathrm{mAU}, 8.6$ 분에서 $8.3 \mathrm{mAU}, 22.4$ 분에서 $0.8 \mathrm{mAU}$ 의 peak를 나타내었다(Fig 1B). 이상의 결과에 따라 L. plantarum 발효를 통해 층꽃나무 $80 \%$ ethanol 추출물과 발효 층꽃나무 $80 \%$ ethanol 추출물 간의 유 용물질의 profile 차이가 존재하는 것을 확인할 수 있었으며, 항 염증 활성에도 차이가 존재할 것으로 예상되었다.

Raw 264.7 cell에서 발효에 따른 세포 생존율 변화(MTT assay) 층꽃나무 추출물의 세포 생존율을 확인하기 위해 층꽃나무 $80 \%$ ethanol 추출물과 발효 $80 \%$ ethanol 추출물을 농도별 $(5,10$, $15,20,30,40,50 \mu \mathrm{g} / \mathrm{mL}$ )로 처리한 결과는 Fig. 2에 나타내었 다. 그 결과는 농도가 증가함에 따라 세포 생존율이 유의적으 로 감소하는 경향을 나타내었으며, 특히 층꽃나무 $80 \%$ ethanol
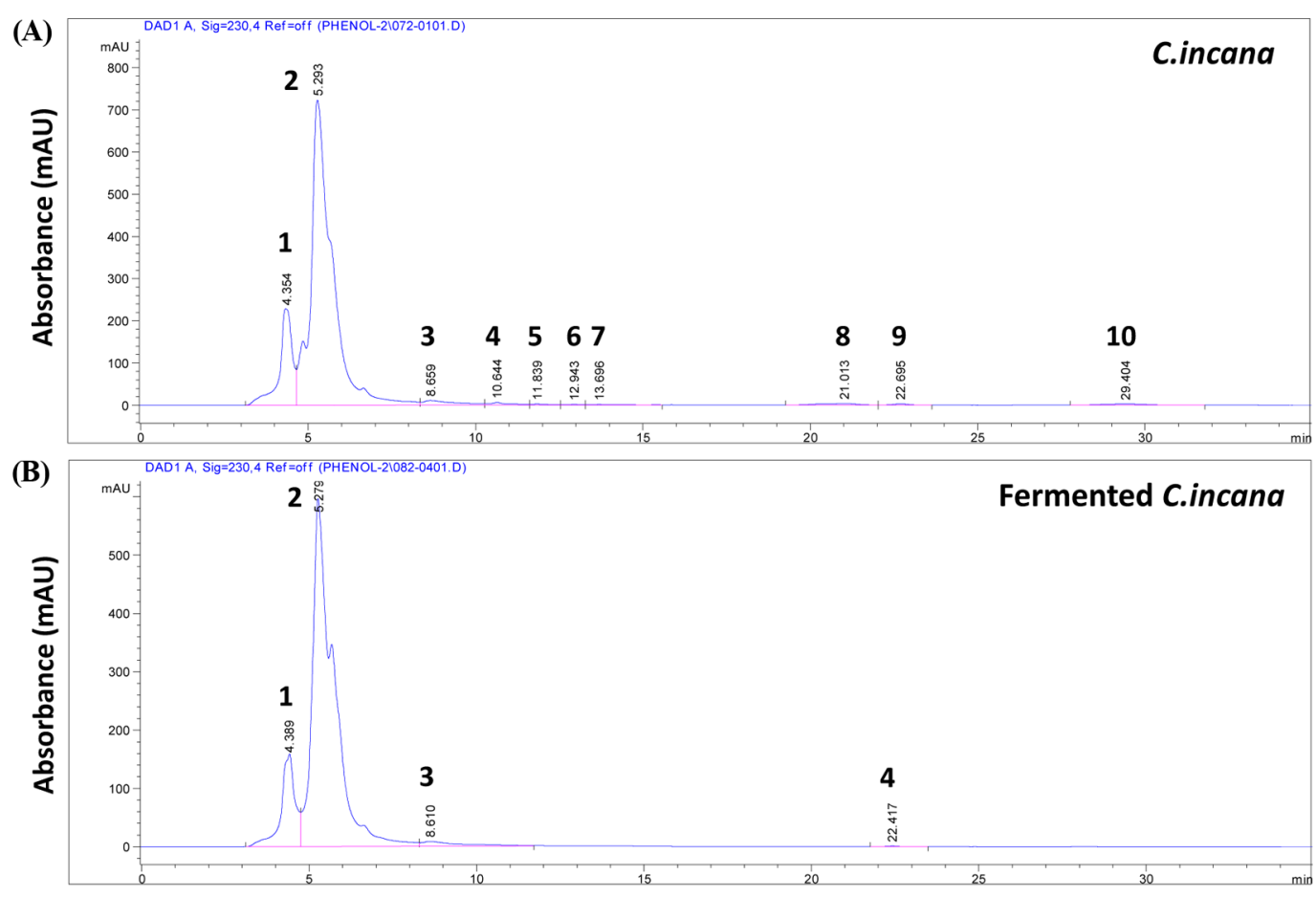

Retention time ( $\mathrm{min})$

Fig. 1 HPLC chromatogram of C. incana $80 \%$ ethnaol extracts. (A): C. incana, (B): Fermented C. incana 

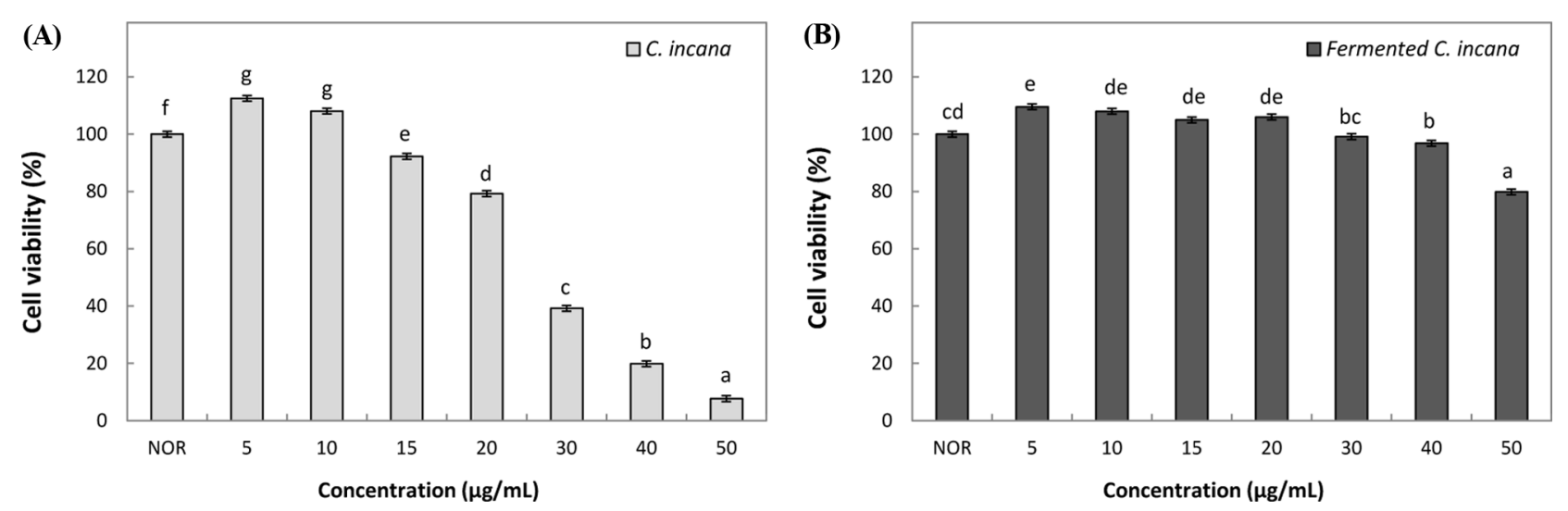

Fig. 2 Cell viability of $C$. incana $80 \%$ extracts on Raw 264.7 cell. (A): C. incana, (B): Fermented C. incana. Means with different letters (a-g) above bars are significantly different at $p<0.05$ by a Duncans multiple range tests

추출물 $20 \mu \mathrm{g} / \mathrm{mL}$ 처리 시 $79.3 \%$ 의 생존율을 나타내어 추출물 자체에 일부 독성이 있는 것으로 확인되었다. 따라서 이후 실 험에서 층꽃나무 $80 \%$ ethanol 추출물의 경우 세포의 생존에 영 향을 미치지 않는 $5,10,15 \mu \mathrm{g} / \mathrm{mL}$ 의 농도로 진행하였다. 반면, 발효 층꽃나무 $80 \%$ ethanol 추출물의 경우, 발효하기 전 독성 을 나타낸 $50 \mu \mathrm{g} / \mathrm{mL}$ 의 높은 농도 처리에서도 생존율이 $77.7 \%$ 를 나타내었으며, 이를 통해 발효가 추출물의 독성을 낮춰주는 것을 확인할 수 있었다. 이상의 결과에 따라 발효 층꽃나무 $80 \%$ ethanol 추출물의 경우, 세포의 생존율에 영향을 미치지 않 는 것으로 판단되는 $10,20,30,40 \mu \mathrm{g} / \mathrm{mL}$ 의 농도에서 이후 실 험을 진행하였으며 발효에 의해 항염증 효과의 변화가 나타나 는지 확인하고자 하였다.

\section{iNOS 및 COX-2 단백질 발현 억제 효과}

$\mathrm{NO}$ 는 여러 조직과 세포에서 L-argine이 $\mathrm{NADPH}$ 에 의해 Lcitrullin으로 산화되는 과정에서 NOS에 의해 합성되는데, 이러 한 NOS는 세 가지 다른 형태의 isoform이 존재한다. 그 중 하 나인 iNOS는 macrophage cell에 작용하여 LPS, IFN- $\gamma$, TNF- $\alpha$ 등에 의해 활성화되어 고농도의 $\mathrm{NO}$ 를 장시간 생성하게 된다. $\mathrm{NO}$ 는 $\mathrm{iNOS}$ 에 의한 발현성이 절대적으로 많으며, $\mathrm{iNOS}$ 의 경우 $\mathrm{NF}-\kappa \mathrm{B}$ 에 의해 transcription level에서 발현량이 조절되는 것으 로 알려져 있으며[23], NF- $\mathrm{kB}$ 는 prostaglandin pathway를 활성 화하여 염증반응과 통증을 유발하는 것으로 알려져 있다. Prosatglandin pathway는 COX라는 효소가 관여하여 arachidonic acid로부터 prostaglandin을 합성하는데[24,25], 두 가지의 isoform 형태를 보이는 COX 중에 COX-2는 TNF- $\alpha$, IL-6, IL$1 \beta$ 와 같은 pro-inflammatory cytokine을 증가시키는 요인 중 하 나로서 염증 조직이나 암 조직에서 높게 나타난다[26]. Western blot을 이용하여 층꽃나무 및 발효 층꽃나무 $80 \%$ ethanol 추출 물의 iNOS 단백질의 발현량을 측정한 결과는 Figs. $3 \mathrm{~A}, \mathrm{~B}$ 와 같다. $\mathrm{iNOS}$ 의 경우 $\mathrm{GAPDH}$ 의 band density 비율에 따라 층꽃 나무 $80 \%$ ethanol 추출물은 $15 \mu \mathrm{g} / \mathrm{mL}$ 농도에서, 발효 층꽃나 무 $80 \%$ ethanol 추출물은 $40 \mu \mathrm{g} / \mathrm{mL}$ 농도에서 각각 약 $50.0 \%$ 의 발현 억제 효과를 나타내었다. Lee 등[27]의 연구결과에서 꽈배기 모자반 비발효군과 Lactobacillus sp. SH-1를 이용한 꽈 배기 모자반 발효군 각각 $100,500 \mu \mathrm{g} / \mathrm{mL}$ 처리했을 때 약
$50.0 \%$ 수준의 $\mathrm{iNOS}$ 저해 활성을 나타내어 이와 비교하였을 때 층꽃나무 및 발효 층꽃나무 $80 \%$ ethanol 추출물이 매우 낮은 농도에서도 우수한 저해 효과를 나타내는 것으로 판단되었다.

한편, 층꽃나무 및 발효 층꽃나무 $80 \%$ ethanol 추출물의 $\mathrm{COX}-2$ 단백질의 발현량을 측정한 결과는 Figs. $3 \mathrm{C}, \mathrm{D}$ 와 같이, $\mathrm{GAPDH}$ 의 band density 비율에 따라 층꽃나무 $80 \%$ ethanol 추출물 $15 \mu \mathrm{g} / \mathrm{mL}$ 농도에서는 $50.0 \%$, 발효 층꽃나무 $80 \%$ ethanol 추출물 $40 \mu \mathrm{g} / \mathrm{mL}$ 농도에서는 $83.0 \%$ 의 발현 억제 효과 를 나타내었다. Kwon 등[28]은 톳 ethanol 추출물은 $500 \mu \mathrm{g}$ / $\mathrm{mL}$ 농도에서 약 $60.0 \%$ 의 발현 억제 효과를 나타내었으며, 유 산균 Weissella sp. SH-1과 Lactobacillus casei를 각각 접종한 톳 ethanol 추출물에서는 각각 $70.0,48.0 \%$ 의 발현 억제 효과를 나타낸다고 보고하여 이와 비교하였을 때, 층꽃나무 및 발효 층 꽃나무 $80 \%$ ethanol 추출물의 iNOS와 COX-2 단백질 발현 억 제 효과가 우수함을 확인할 수 있었다. 특히 COX-2의 경우, 발 효를 통해 층꽃나무 $80 \%$ ethanol 추출물의 세포독성을 일부 감 소시켜 독성이 낮아진 안전한 추출물을 높은 농도로 처리할 수 있게 되었으며, 안전한 유용성분의 함량 증대로 인해 COX-2 단백질 발현의 저해 효과도 증폭될 수 있음을 알 수 있었다. 따 라서 발효한 층꽃나무 추출물이 층꽃나무 추출물 보다 훨씬 안 전하고 우수한 면역 증진 소재로 유용하게 활용될 수 있을 것 으로 기대되었다.

\section{$\mathrm{NO}$ 및 $\mathrm{PGE}_{2}$ 저해 효과}

$\mathrm{NO}$ 는 L-argine으로부터 NOS 에 의해 생성되는 무기 유리체로, $\mathrm{NO}$ 의 기능은 전염성 박테리아와 곰팡이를 사멸시키고 종양을 제거하여 신체를 지켜주는 것이다. 하지만, 병리학적인 원인에 의해 과도하게 $\mathrm{NO}$ 가 형성되면 세포 내에 염증을 유발하게 되 며, 면역체계의 부작용, 조직의 손상, 유전자 변이 및 신경계의 손상 등을 유발한다[29]. LPS로 유도된 Raw 264.7 cell에 층꽃 나무 및 발효 층꽃나무 $80 \%$ ethanol 추출물을 처리하여 생성 되는 $\mathrm{NO}$ 양을 측정한 결과는 Figs. $4 \mathrm{~A}, \mathrm{~B}$ 와 같다. $\mathrm{LPS}$ 를 처리 하지 않은 normal군에 비해 LPS만 처리한 control군이 5배 이 상의 NO 생성량을 나타내었으며, 층꽃나무 $80 \%$ ethanol 추출 물의 경우 농도가 높아질수록 $\mathrm{NO}$ 생성량이 감소하는 것을 확 인할 수 있었다. 특히 $15 \mu \mathrm{g} / \mathrm{mL}$ 농도에서는 control군에 비해 

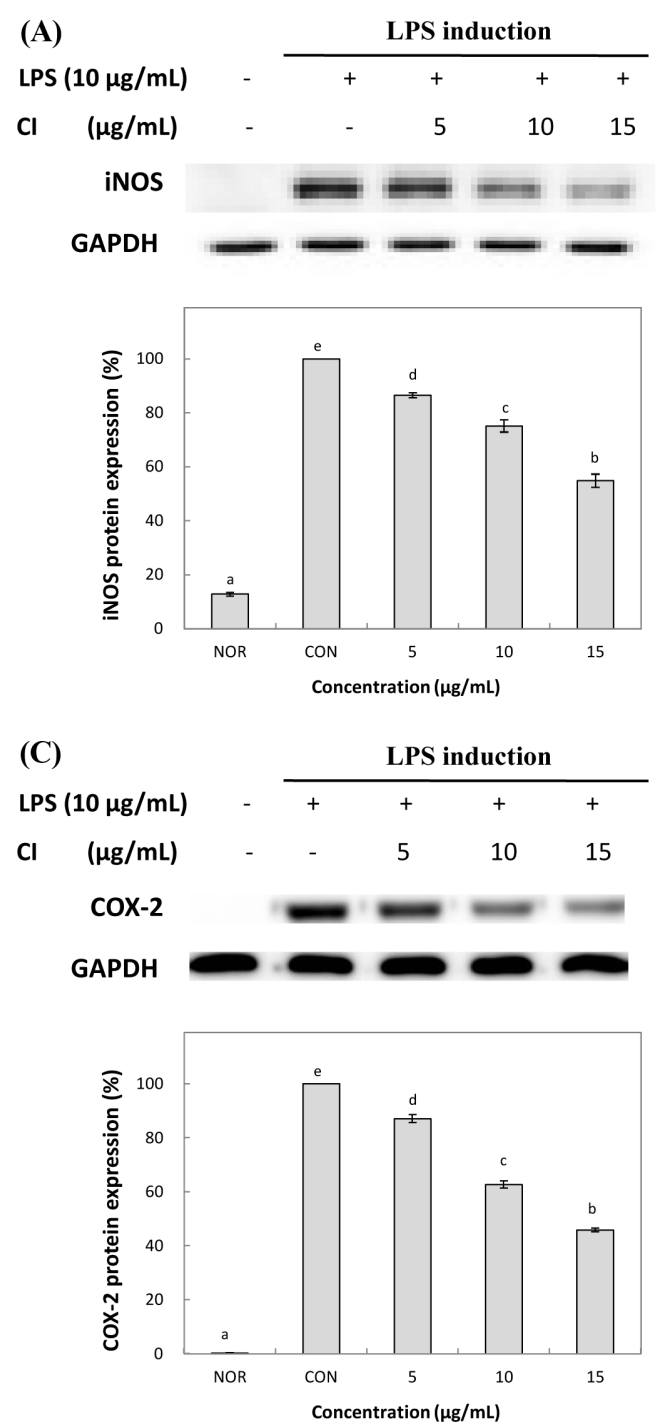
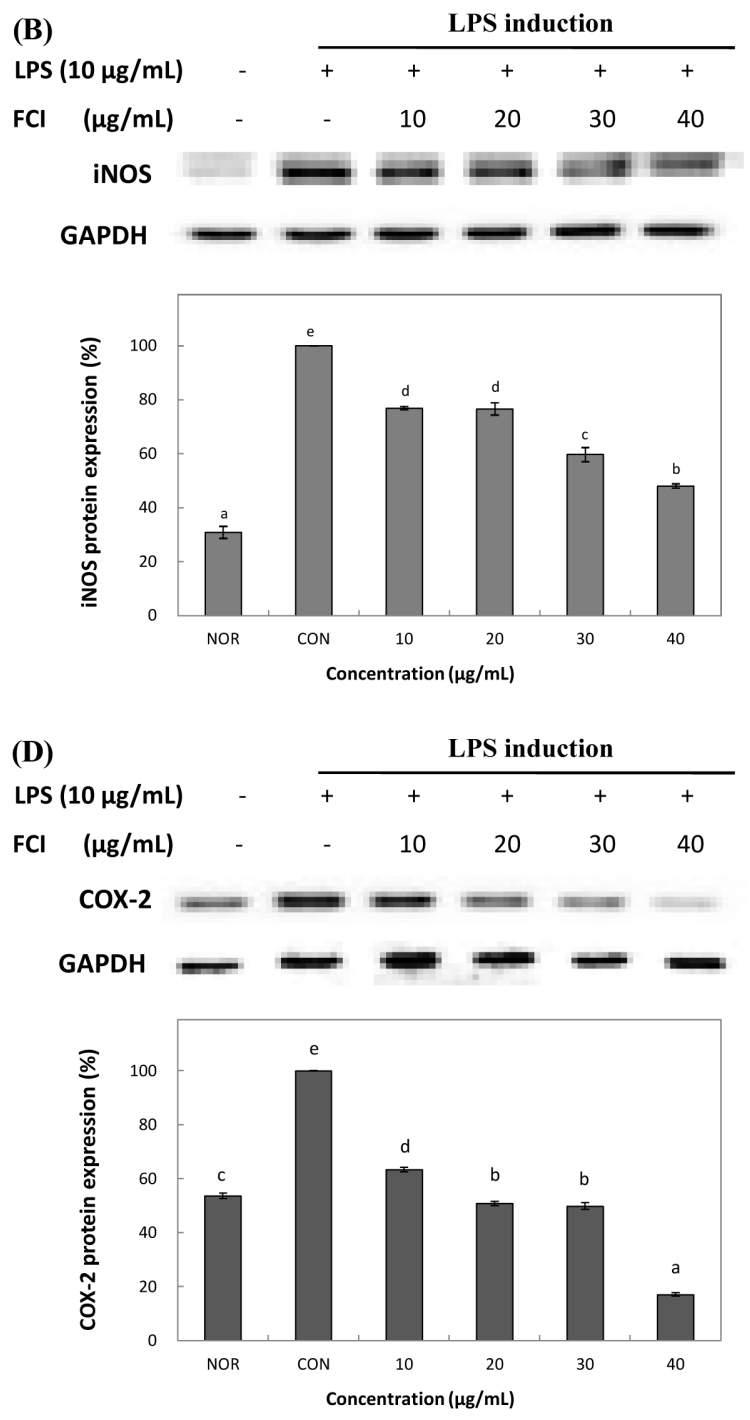

Fig. 3 Inducible iNOS and COX-2 protein expression rate of $C$. incana extracts on Raw 264.7 cell. (A): iNOS protein expression rate of $C$. incana, (B): iNOS protein expression rate of fermented $C$. incana. (C): COX-2 protein expression rate of $C$. incana, (D): COX-2 protein expression rate of fermented $C$. incana. Histogram show the dessitometric of iNOS protein normalized to GAPDH. Means with different letters (a-e) above bars are significantly different at $p<0.05$ by a Duncans multiple range tests

$62.0 \%$ 의 NO 생성 억제 효과를 나타내었다. 또한, 발효 층꽃나 무 $80 \%$ ethanol 추출물은 $40 \mu \mathrm{g} / \mathrm{mL}$ 농도에서 control군에 비해 $81.0 \%$ 의 NO 생성 저해율을 보여주어 normal군과 비슷한 수준 의 효과를 나타내었다. Jung과 Cho의 연구[30]에 따르면 비발 효 대추 ethanol 추출물과 S. cerevisiae와 B. breve를 이용한 발효 대추 ethanol 추출물은 $500 \mu \mathrm{g} / \mathrm{mL}$ 의 농도에서 각각 90.0 , $68.0,66.0 \%$ 의 NO 생성 저해율을 나타내어 미생물 발효가 생 리활성 변화에 좋은 영향을 미치는 것으로 한단되었다. 이상의 결과를 통해 층꽃나무 및 발효 층꽃나무 $80 \%$ ethanol 추출물 의 $\mathrm{NO}$ 생성 억제 효과가 매우 우수함을 알 수 있을 뿐만 아 니라 발효를 통해 층꽃나무가 지닌 세포 독성을 감소시키고, 이 를 통해 안전성이 확보된 유용성분의 함량을 더 증가시켜 사용 할 수 있게 되어 $\mathrm{NO}$ 생성 억제 효과를 향상시키는 것으로 간 주할 수 있었다.
반면, $\mathrm{PGE}_{2}$ 는 통증과 발열의 전달에 주로 관여하는 중요한 염증 매개물질로서, phospholipase $\mathrm{A}_{2}$ 에 의해 유리된 arachidonic acid를 이용하여 COX-1과 COX-2가 prostaglandin $\mathrm{H}_{2}$ 를 생성한 다음 $\mathrm{PGE}_{2}$, prostacycline, thromboxane $\mathrm{A}_{2}$ 로 변환된다[31]. $\mathrm{PGE}_{2}$ 의 생성량을 측정한 결과는 Figs. $4 \mathrm{C}, \mathrm{D}$ 와 같이 층꽃나무 $80 \%$ ethanol 추출물은 $15 \mu \mathrm{g} / \mathrm{mL}$ 농도에서, 발효 층꽃나무 $80 \%$ ethanol 추출물은 $30 \mu \mathrm{g} / \mathrm{mL}$ 농도에서 각각 약 $70.0 \%$ 수준의 발 현을 억제하여 normal군과 유사한 수준의 효과를 나타내었다. Lee 등[32]은 적하수오 ethanol 추출물이 $100 \mu \mathrm{g} / \mathrm{mL}$ 의 높은 농 도에서 $70.0 \%$ 수준의 발현 억제 효과를 나타내었고, Tak 등 [33]의 L. rhamnosus를 이용한 흑마늘 발효물의 경우 $800 \mu \mathrm{g}$ / $\mathrm{mL}$ 의 높은 농도에서 $10.0 \%$ 의 발현 억제 효과를 나타낸 것과 비교하였을 때, 층꽃나무 및 발효 층꽃나무 $80 \%$ ethanol 추출 물이 훨씬 우수한 효과를 가지는 것으로 확인되었다. 

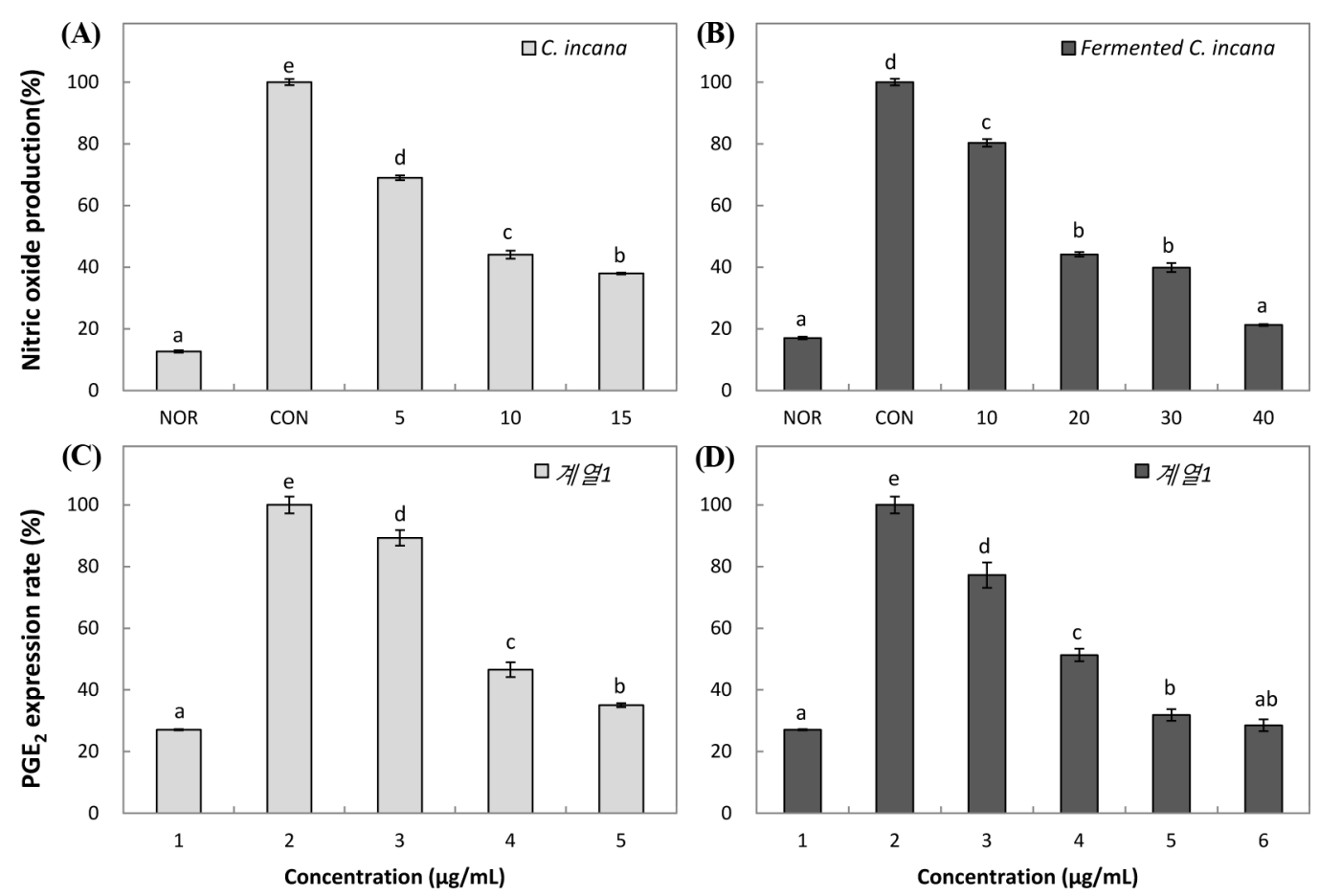

Fig. 4 Inhibition rate of $C$. incana extracts on $\mathrm{NO}$ and $\mathrm{PGE}_{2}$. (A): $\mathrm{NO}$ inhibition rate of $C$. incana, (B): $\mathrm{NO}$ inhibition rate of fermented $C$. incana. (C): $\mathrm{PGE}_{2}$ inhibition rate of $C$. incana, (D): $\mathrm{PGE}_{2}$ inhibition rate of fermented $C$. incana. Means with different letters (a-e) above bars are significantly different at $p<0.05$ by a Duncans multiple range tests

\section{Pro-inflammatory cytokine (TNF- $\alpha$, IL-6, IL-1 $\beta$ ) 생성 억제 효과}

Pro-inflammatory cytokine은 염증 면역 반응에서 필연적으로 동 반되는 매개물질이며 정상적인 조직에서 발현되나 병리적인 조 건에서 그 발현 정도가 증가되는데, 이로 인해 노화가 촉진되 며 질환이 더욱 악화된다[34]. 그 중 $\mathrm{TNF}-\alpha$ 는 염증 반응 초기 에 해당 부위로 호중구를 유도하며 지속적인 생성은 다른 염증 세포를 활성화시켜 cytokine, iNOS, COX-2의 발현량이 증가되 고, 이로 인해 만성 염증이 유발되어 자가면역질환, 류마티스 관절염에 관여하는 것으로 알려져 있다[35]. 대표적인 proinflammatory cytokine인 IL-6는 B-cell이 형질세포로 분화되는 과정을 촉진하여 항체 생산을 증가시키지만 과잉 생산될 경우 감염성 질환을 유발한다[36]. 또한 IL- $1 \beta$ 도 세균감염에 대한 염 증성 응답의 개시 및 강화에 중요한 역할을 하며 저농도에서 세포성장과 항상성 유지에 필수적인 cytokine이지만, 대량 생산 될 경우 T-cell을 활성화 시키고 B-cell을 성숙시켜 염증성 질환 을 악화시키게 된다[37]. 층꽃나무 $80 \%$ ethanol 추출물의 proinflammatory cytokine의 생성 억제 효과를 확인하기 위해 먼저 $\mathrm{TNF}-\alpha$ 생성 억제 효과를 측정한 결과는 각각 층꽃나무 $80 \%$ ethanol 추출물 $15 \mu \mathrm{g} / \mathrm{mL}$ 농도에서 $43.6 \%$, 발효 층꽃나무 $80 \%$ ethanol 추출물 $40 \mu \mathrm{g} / \mathrm{mL}$ 농도에서 $75.4 \%$ 의 저해율을 나타내었 다(Figs. 5A, B). 또한 IL-6 생성 억제 효과는 층꽃나무 $80 \%$ ethanol 추출물 $15 \mu \mathrm{g} / \mathrm{mL}$ 농도에서 $64.3 \%$, 발효 층꽃나무 $80 \%$ ethanol 추출물 $40 \mu \mathrm{g} / \mathrm{mL}$ 농도에서 $67.7 \%$ 의 저해율을 나타내었 으며(Figs. $5 \mathrm{C}, \mathrm{D}), \mathrm{IL}-1 \beta$ 생성 억제 효과는 각각 층꽃나무 $80 \%$ ethanol 추출물 $15 \mu \mathrm{g} / \mathrm{mL}$ 농도에서 $58.7 \%$, 발효 층꽃나무
$80 \%$ ethanol 추출물 $40 \mu \mathrm{g} / \mathrm{mL}$ 농도에서 $64.6 \%$ 의 저해율을 나 타내었다(Figs. 5E, F). Yang 등[38]의 S. cerevisiae STV89를 이용한 황금 발효물의 $200 \mu \mathrm{g} / \mathrm{mL}$ 의 농도에서 $60.0 \%$ 의 IL-6의 발현 억제 효과를 나타낸 결과와, Han 등[39]의 고삼, 감초, 백 선피 ethanol 추출물 $20 \mu \mathrm{g} / \mathrm{mL}$ 의 농도에서 $50.0 \%$ 의 IL- $1 \beta$ 발 현 억제 효과를 보고한 연구와 비교하였을 때, 층꽃나무 뿐만 아니라 발효 층꽃나무 $80 \%$ ethanol 추출물의 pro-inflammatory cytokine 억제 효과가 매우 우수하다는 것을 확인할 수 있었다. 본 연구 결과를 통해 층꽃나무 ethanol 추출물에 염증을 매개하 는 단백질 및 cytokine의 발현을 저해시키는 우수한 유용성분이 함유되어 있음을 알 수 있었다. 또한 L. plantarum을 이용하여 발효시킨 경우, 층꽃나무 유용성분의 profile을 변화시켰으며, 이 러한 대사물의 전환으로 인해 층꽃나무가 가지고 있던 세포독 성을 일부 감소시켜 유용성분의 안전성을 증폭시키는 것을 확 인할 수 있었다. 따라서 미생물을 이용한 발효 기법이 최종 대 사산물을 독성을 낮추고, 사용량을 높일 수 있는 유용한 기술 임을 판단할 수 있었다.

\section{초 록}

본 연구에서는 층꽃나무와 L. plantarum으로 발효한 층꽃나무 를 각각 $80 \%$ ethanol로 추출하여 추출물들이 LPS로 유도된 Raw 264.7 cell의 염증반응에 미치는 영향을 비교 검증하여 항 염증 소재 개발 가능성을 검토하였다. HPLC를 이용하여 $L$. plantarum 에 의한 층꽃나무 발효 추출물의 유용성분 변화를 확 

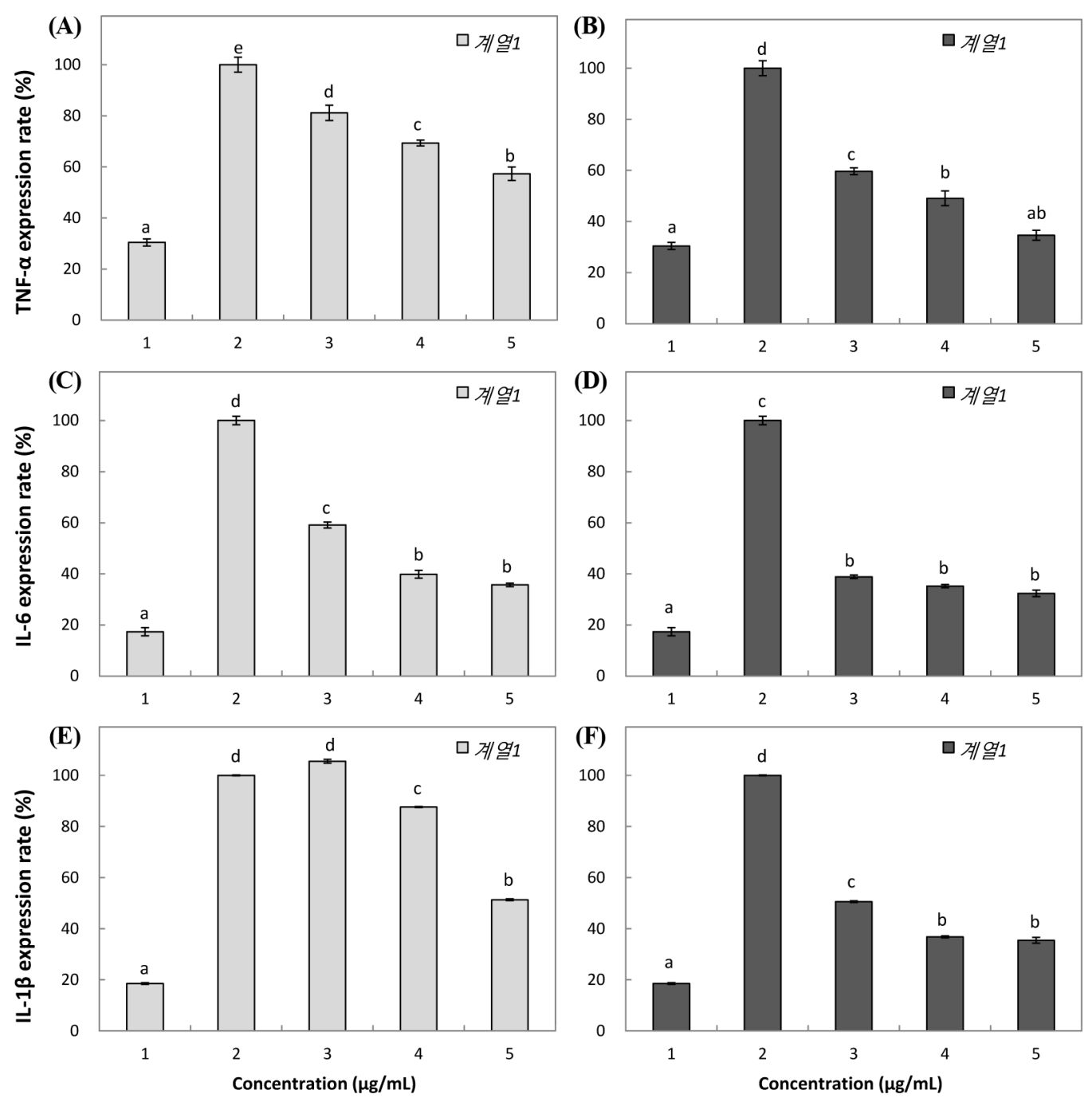

Fig. 5 Inhibition rate of $C$. incana extracts on pro-inflammatory cytokine. (A): TNF- $\alpha$ inhibition rate of $C$. incana, (B): TNF- $\alpha$ inhibition rate of fermented $C$. incana. (C): IL-6 inhibition rate of $C$. incana, (D): IL-6 inhibition rate of fermented $C$. incana. (E): IL-1 $\beta$ inhibition rate of $C$. incana, (F): IL-1 $\beta$ inhibition rate of fermented $C$. incana. Means with different letters (a-e) above bars are significantly different at $p<0.05$ by a Duncans multiple range tests

인한 결과, 발효를 통해 유용성분의 profile 변화가 있는 것을 확인할 수 있었다. Raw 264.7 cell에서 세포 독성을 측정하기 위해 MTT assay를 실시한 결과, 층꽃나무 $80 \%$ ethanol 추출물 은 $5,10,15 \mu \mathrm{g} / \mathrm{mL}$ 의 농도에서 발효 층꽃나무 $80 \%$ ethanol 추출물의 경우 $10,20,30,40 \mu \mathrm{g} / \mathrm{mL}$ 의 농도에서 $90.0 \%$ 이상 의 세포 생존율을 나타내었다. 항염증 효능을 검정하기 위해 $\mathrm{iNOS}$ 단백질 발현량, $\mathrm{COX}-2$ 단백질 발현량, $\mathrm{NO}$ 생성, $\mathrm{PGE}_{2}$ 생성, pro-inflammatory cytokine 발현량을 측정하였다. NO 생 합성 효소인 iNOS 단백질의 발현량을 측정한 결과, 층꽃나무 와 발효 층꽃나무 $80 \%$ ethanol 추출물은 각각 $15,40 \mu \mathrm{g} / \mathrm{mL}$ 의 농도에서 약 $50.0 \%$ 가까운 발현 억제 효과를 나타내었으며, 농 도 의존적으로 감소하는 것을 확인할 수 있었다. $\mathrm{PGE}_{2}$ 생합성 효소인 COX-2 단백질의 발현량을 측정한 결과, 층꽃나무 $80 \%$ ethanol 추출물은 $15 \mu \mathrm{g} / \mathrm{mL}$ 농도에서 $50.0 \%$, 발효 층꽃나무 $80 \%$ ethanol 추출물은 $40 \mu \mathrm{g} / \mathrm{mL}$ 농도에서 $83.0 \%$ 의 발현 억제
효과를 보여주었다. $\mathrm{NO}$ 생성 억제 효과를 측정한 결과 층꽃나 무 $80 \%$ ethanal 추출물은 $15 \mu \mathrm{g} / \mathrm{mL}$ 농도에서 $62.0 \%$, 발효 층 꽃나무는 $40 \mu \mathrm{g} / \mathrm{mL}$ 농도에서 $81.0 \%$ 로 control군과 비교하였을 때 $\mathrm{NO}$ 생성이 크게 억제되었다. $\mathrm{PGE}_{2}$ 생성 억제 효과를 측정 한 결과, 층꽃나무와 발효 층꽃나무 $80 \%$ ethanal 추출물은 각 각 $15,30 \mu \mathrm{g} / \mathrm{mL}$ 의 농도에서 약 $70.0 \%$ 의 발현 억제 효과를 나 타내었다. 또한, pro-inflammatory cytokine의 경우, 층꽃나무 $80 \%$ ethanol 추출물 $15 \mu \mathrm{g} / \mathrm{mL}$ 농도에서 $\mathrm{TNF}-\alpha$ 는 $43.6 \%$, IL6 는 $64.3 \%, \mathrm{IL}-1 \beta$ 는 $58.7 \%$ 의 저해율을 나타냈으며, 발효 층꽃 나무 $80 \%$ ethanol 추출물 $40 \mu \mathrm{g} / \mathrm{mL}$ 농도에서 $\mathrm{TNF}-\alpha$ 는 $75.4 \%, \mathrm{IL}-6$ 는 $64.3 \%, \mathrm{IL}-1 \beta$ 는 $37.7 \%$ 의 발현 억제 효과를 나 타내었다. 이상의 결과를 통해 층꽃나무는 매우 우수한 항염증 효과를 나타내는 소재임을 확인할 수 있었으며, L. plantarum균 을 이용한 발효를 통해 층꽃나무가 가진 세포 독성을 낮추어 안전성하고 우수한 효능을 가진 새로운 항염증제로 개발 가능 
한 소재로 활용될 수 있을 것으로 기대되었다.

Keywords 대식세포·발효 · 유산균·층꽃나무 · 항염증

\section{References}

1. Choi SY, Lee HR (1976) Host preference by the small brown planth opper and green rice leafhopper on barley and water foxtail. Kor J Pl Prot 15: 179-181

2. Higuchi M, Higashi N, Taki H, Osawa T (1990) Cytolytic mechanisms of activated macrophages. Tumar necrosis factor and L-argininedependent mechanisms acts synergistically as the major cytolytic mechanisms of activated macrophages. J Immunol 144: 1434-1441

3. Chow JC, Young DW, Golenbock DT, Christ WJ, Gusovsky F (1999) Toll-like receptor-4 mediates lipopolysaccharide-induced signal transduction. J Biol Chem 274: 10689-10692

4. Yang F, Tang E, Guan K, Wang CY (2003) IKK $\beta$ plays an essential role in the phosphorylation of RelA/p65 on serine 536 induced by lipopolysaccharide. J Immunol 170: 5630-5635

5. Bhattacharyya S, Ratajczak CK, Vogt SK, Kelle C, Colonna M, Schreiber RD, Muglia LJ (2010) TAK1 targeting B by glucocorticoids determines JNK and IKB regulation in Toll-like receptor-stimulated macrophages. Blood 115: 1921-1931

6. Surh YJ, Chun KS, Cha HH, Keum YS, Park KK, Lee SS (2001) Molecular mechanisms underlying chemopreventive activities of antiinfammatory phytochemicals: down-regulation of COX-2 and iNOS through suppression of NF-KB activation. Mutat Res 480: 243-268

7. Barnes PJ, Liew FY (1995) Nitric oxide and asthmatic inflammation. Immunol Today 16: 128-130

8. Smith WL, Michael GR, DeWitt DL (1996) Prostaglandin endoperoxide Hsynthase (cyclooxygenase)-1 and -2. J Biol Chem 271: 33157-33160

9. Lee TB (2003) Coloured flora of korea. Vol. 2. Hyangmunsa, Seoul, Korea. pp 112-119

10. Chang KC, Lee DU (2000) Vasodilatory effect of the alkaloid component from the roots of Cynanchum wilfordi Hemsley. Korean J Life Sci 10: 584-590

11. Bae MJ, Ye EJ (2007) Effect of mycelia extracts from Lentinus edodes musfroom-cultured Lonicera japonica thunbergs on anticancer and antiallergy activities. J Korean Soc Food Sci Nutr 36: 424-430

12. Lee SC, Kim SY, Choi SJ, Lee IS, Jung MY, Yang SM, Chae HJ (2010) Effect of soaking and heat treatment conditions on physicochemical and organoleptic quality of lotus root. Korean J Food Sci Technol 42: 45-49

13. Yoshikawa K, Harada A, Iseki K, Hashimoto T (2014) Constituents of Caryopteris incana and their antibacterial activity. J Nat Med 68: 231235

14. Yang HJ, Joo HA, Baek SC, Park JS, Hong SH (2011) Antiinflammatory effects of hwangnyeonhaedok-tang and fermented hwangnyeonhaedok-tang. J Korean Med Ophthalmol Otolaryngol Dermatol 24: $1-15$

15. Doh ES, Chang JP, Kil KJ, Choi MS, Yang JK, Yun CW, Jeong SM, Jung YH, Lee GH (2011) Antioxidative activity and cytotoxicity of fermented Allium victorialis L. extract. Korean J Plant Res 24: 30-39

16. Park MR, Yoo C, Chang YN, Ahn BY (2012) Changes of total polyphenol content of fermented Gastrodia elata blume and radical scavenging. Korean J Plant Res 25: 379-386

17. Park HJ, Jung DH, Joo HM, Kang NS, Jang SA, Lee JG, Sohn EH (2010) The comparative study of anti-allergic and anti-inflammatory effects by fermented red ginseng and red ginseng. Korean J. Plant Res 23: $415-422$

18. Lim HW, Lee YJ, Huang YH, Yoon JY, Lee SH, Kim KH, Lim CJ (2017) Enhancement of skin antioxidant and anti-inflammatory potentials of Agastache rugosa leaf extract by probiotic bacterial fermentation in human epidermal keratinocytes. Microbiol Biotechnol Lett 45: 35-42

19. Lee JE, Lee EH, Kim BO, Cho YJ (2017) Biological activities of extracts from Caryopteris incana Miq. J Appl Biol Chem 60: 61-68

20. Folin O, Denis W (1912) On phosphotungstic-phosphomolybdic compounds as color reagents. J Biol Chem 12: 239-249

21. Carmichael J, DeGraff WG, Gazder AF, Minna JD, Mitchell JB (1987) Evalution of a tetrazolium based semiautomated colorimetric assay: assessment of chemosensitivity testing. Cancer Res 47: 936-942

22. Ryu JH, Ahn H, Kim JY, Kim YK (2003) Inhibitory activity of plant extracts on nitric oxide synthesis in LPS-activated macrophage. Phytother Res 17: 485-489

23. Kim SH (2005) Effect of the aqueous extracts of Pogostemi Herba on Nitric oxide synthesis and activation of cytokine in macrophage. Dissertation, Ajou University

24. Weng SX, Sui MH, Chen S, Wang JA, Xu G, Ma J, Shan J, Fang L (2009) Parthenolide inhibits proliferation of vascular smooth muscle cells through induction of $\mathrm{G}_{0} / \mathrm{G}_{1}$ phase cell cycle arrest. J Zhejiang Univ Sci B 10: 528-535

25. Stachowska E, Dolegowska B, Dziedziejko V, Rybicka M, Kaczmarczyk M, Bober J, Rac M, Machalinski B, Chlubek D (2009) Prostaglandin E $\left(\mathrm{PGE}_{2}\right)$ and thromboxane $\mathrm{A}_{2}\left(\mathrm{TXA}_{2}\right)$ synthesis is regulated by conjugated linoleicacids (CLA) in human macrophages. J Physiol Pharmacol 60: 77-85

26. Yu Y, Fan JJ, Hui Y, Rouzer CA, Marnett LJ, Klein-Szanto AJ, FitzGerald GA, Funk CD (2007) Targeted cyclooxygenase gene (Ptgs) exchange reveals discriminant isoform functionality. J Biol Chem 282: $1498-1506$

27. Lee SJ, Lee DG, Kim MH, Kong CS, Yu KH, Kim YY, Lee SH (2016) Enhancement of anti-inflammatory activity by fermented of Sargassum siliquanstrum. J Life Sci 26: 318-324

28. Kwon MS, Mum OJ, Bae MJ, Lee SG, Kim MH, Lee SH, Yu KH, Kim YY, Kong CS (2015) Anti-inflammatory activity of ethanol extracts from Hizikia fusiformis fermented with lactic acid bacteria in LPS-stimulated RAW 264.7 macrophages. J Korean Soc Food Sci Nutr 44: 1450-1457

29. Cho YJ, Ahn BJ (2008) Anti-inflammatory effect of extracts from Cheongmoknosang (Morus alba L.) in lipopolysaccharide stimulated Raw cells. J Korean Soc Appl Biol Chem 51: 44-48

30. Jung JE, Cho EJ (2011) Enhancement of anti-inlammatory effect of Zizyphus jujuba var. intermis fruits by fermentation. Cancer Prev Res 14: $57-62$

31. Kim KB, Lee EG, Chai OH, Song CH, Jeong JM (2007) Inhibitory effects of Phyto-extracts mixture (PEM381) on type allergic reaction. J Korean Soc Food Nutr 36: 155-162

32. Lee ES, Kim HJ, Yu JM, Cho YH, Kim DI, Cho YJ, An BJ (2014) Antiinflammatory effect of Polygonum multiflorum extraction in activated RAW 264.7 cells with lipopolysaccharide. Korean J Food Preserv 21: 740-746

33. Tak HM, Kang MJ, Kim KM, Kang DW, Han SY, Shin JH (2014) Antiinflammatory activities of fermented black garlic. J Korean Soc Food Sci Nutr 43: 1527-1534

34. Park SG, Jeal KH, Jung JY, Back YD, Byun SH, Kim YW, Cho IJ, Park SM, Kim SC (2014) Leonuri fructus ameliorates acute inflammation via the inhibition of NF-kB-mediated nitric oxide and pro-inflammatory cytokine production. Korean J Orient Physol Pathol 28: 178-185

35. Dinarello CA (1999) Cytokines as endogenous pyrogens. J Infect Dis 179: 294-304

36. Delgado AV, McManus AT, Chambers JP (2003) Production of tumor necrosis factor- $\alpha$, interleukin $1-\beta$, interleukin 2 and interleukin 6 by rat leukocyte subpopulations after exposure to substance. P neuropeptides 37: $355-361$

37. Lebovic DI, Betzien F, Chao VA, Garrett EN, Meng YG, Taylor RN (2000) Induction of an angiogenic phenotype in endometriotic stromal cell cultures by interleukin-1 $\beta$. Mol Hum Reprod 6: 269-275

38. Yang HJ, Han HS, Lee YJ (2013) Effect of fermented scutellariae radix 
extract on production of inflammatory mediator in LPS-stimulated mouse macrophges. Kor J Herbology 28: 45-52

39. Han MH, Lee MH, Hong SH, Choi YH, Moon JS, Song MK, Kim MJ, Shin SJ, Hwang HJ (2014) Comparison of anti-inflammatory activities among ethanol extracts of Sophora flavescens, Glycyrrhiza uralensis and Dictamnus dasycarpus and their mixture in RAW 264.7 murine macrophages. J Life Sci 24: 329-335 